\title{
Context Clues Knowledge and Reading Comprehension Skills of Grade 10 Students
}

\author{
Cynthia O. Jomocan ${ }^{1}$ and Ma. Judy B. Legaspi ${ }^{2}$ \\ ${ }^{1}$ Sum-ag National High School, Bacolod City, Philippines \\ ${ }^{2}$ University of Negros Occidental-Recoletos, Bacolod City, Philippines
}

\begin{tabular}{l} 
Article history \\
Submitted: 23 October 2020 \\
Revised: 5 November 2020 \\
Accepted: 12 November 2020 \\
\hline Keywords \\
Language Education \\
Context Clues \\
Reading Comprehension \\
Grade 10 Students \\
Descriptive-Correlative \\
Bacolod City
\end{tabular}

Introduction. One of the goals of education is to develop learners with strong reading and comprehension skills. Memorandum No. 173 s. 2019 of the Department of Education strongly encouraged all elementary and secondary public schools to intensify their advocacy for independence in reading in all grade levels and align the promotion of reading culture as the key in closing achievement gaps in producing productive citizens. It is a fact that many Filipino learners struggle to meet the standards in English communication and language. Given the literature gap, this study determined the level of context clues knowledge and level of reading comprehension skills of Grade 10 students in the three-class programs: Basic Education Curriculum (BEC), Science Technology (STE), and the Strengthened Technical Vocational Education Program (STVEP) of a public junior high school in the Division of Bacolod City. The study also determined the difference in the level of context clues knowledge and level of reading comprehension skills of the students when grouped according to class programs and explored the relationship between context clues knowledge and reading comprehension skills.

Methods. Descriptive, comparative, and correlational design was used in this study. Using stratified random sampling, 246 Grade 10 students enrolled in a public high school in the Division of Bacolod City during the school year 2019-2020 were the respondents. Through a validated and reliabilitytested researcher-made questionnaire, data were obtained, which underwent descriptive analysis using the Mean and Standard Deviation in determining the level of context clues knowledge and reading comprehension skills as a whole and grouped according to class programs. To determine the significant difference in the level of context clues knowledge and reading comprehension skills when the respondents were grouped according to class program, comparative analysis using Kruskal-Wallis and Dunn's test was employed. To examine the relationship between context clues knowledge and reading comprehension skills, correlational analysis using Spearman rank correlation was utilized.

Results. Findings revealed that the level of context clues knowledge as a whole is average, signifying an acceptable level of context clues knowledge. When grouped according to class programs, BEC resulted in average or acceptable, STE got very high or excellent, and STVEP had very good levels. For the level of reading comprehension, the result as a whole is expanding or acceptable reading proficiency skills at all levels. As to class programs, BEC revealed expanding or acceptable level, while STE and STVEP got accomplished or very good level. A significant difference was noted in the level of context clues knowledge when the students were grouped according to class programs. Also, a significant difference was recorded in the students' reading comprehension in the literal, inferential, and critical levels when they were grouped according to class programs. Lastly, a significant relationship was established between context clues knowledge, and reading comprehension.

Conclusion. The use of context clues is geared toward enhancing reading skills in the literal, inferential, and critical levels. The nature of the class program, the instruction, the curriculum, and the teaching styles are factors to consider in the students' performance. The STE performance could be attributed to the quality of English instruction, the inclusion of the research subject, and the use of the spiral progression approach. The performance of the STVEP could be linked to the training and quality of English instruction also. The performance of the BEC is explained by the basic reading instruction in the curriculum. Despite the rigorous instruction in English, the said class revealed 
an average level in context clues knowledge and weakness in the critical area, signifying a need to address their weaknesses through instructional materials. The significant relationship between context clues knowledge and reading comprehension reminds English teachers to utilize instructions and descriptive approaches in assessing the effectiveness of the English instruction.

Practical Value of the Paper. Based on the results of the study, the research prepared supplementary activity worksheets as instructional materials to be used to remediate the difficulties students have over the use of context clues to improve their reading comprehension skills. Addressing these difficulties would be a measure that can prepare the students for the next English instruction level. The researcher recommends using these instructional materials to help students develop their reading skills through distance learning under the "new normal" educational system.

\section{References}

Boonchum, P. (2018). English Reading Efficiency of Non-English-Major Students via Context Clues Reading Drills. Journal of Community Development Research (Humanities and Social Sciences), 11(4), 118-125.

Roohr, K. C., \& Burkander, K. (2020). Exploring Critical Thinking as an Outcome for Students Enrolled in Community Colleges. Community College Review, 48(3), 330-351.

Cabardo, J. R. (2015). Reading Proficiency Level of Students: Basis for Reading Intervention Program. Available at SSRN 2712237.

Fong, C. J., Kim, Y., Davis, C. W., Hoang, T., \& Kim, Y. W. (2017). A meta-analysis on critical thinking and community college student achievement. Thinking Skills and Creativity, 26, 71-83.

Hall, C., Vaughn, S., Barnes, M. A., Stewart, A. A., Austin, C. R., \& Roberts, G. (2020). The effects of inference instruction on the reading comprehension of English learners with reading comprehension difficulties. Remedial and Special Education, 41(5), 259-270.

Mauliza, R., Samad, I. A., \& Erdiana, N. (2019). The Implementation of Context Clues Strategy in Inferring the Meaning of Unknown Vocabulary to Improve Reading Skills. Research in English and Education Journal, 4(2), 80-88.

Putri, E. W., Fauzan, U., \& Toba, R. (2018). The Quality of Listening Skills of the EFL Students. IJELTAL (Indonesian Journal of English Language Teaching and Applied Linguistics), 3(1), 79-90.

Putri, M., \& Fitrawati, F. (2019). The Correlation Between Context Clues Strategy and Reading Comprehension Ability at the Second Semester English Department Students of Universitas Negeri Padang. Journal of English Language Teaching, 8(4), 472-483.

Ubamos, G. U., \& Aboy, I. G. (2019). Morphemic and Semantic Analyses Skills of Senior High School Students. Philippine Social Science Journal, 2(2), 91-106.

Vernandes, Y. (2019). THE INFLUENCE OF CONTEXT CLUES STRATEGY ON STUDENTS'READING ACHIEVEMENT. Esteem Journal of English Education Study Programme, 2(2), 154-159.

\section{Correspondence:}

Cynthia O. Jomocan [jomocan.c@yahoo.com]

https://orcid.org/0000-0001-5527-1033 